\title{
Effects of extracts derived from roots and stems of Chelidonium majus L. on oxidative stress biomarkers in the model of equine plasma
}

\author{
Nataniel Stefanowski, Halyna Tkachenko*, Natalia Kurhaluk \\ Institute of Biology and Earth Sciences, Pomeranian University in Słupsk, Poland \\ ORCID \\ Halyna Tkachenko: https://orcid.org/0000-0003-3951-9005 \\ Natalia Kurhaluk: https://orcid.org/0000-0002-4669-1092
}

Article Details:

Received: $\quad$ 2021-06-20

Accepted: 2021-07-18

Available online: 2021-11-30

DOI: https://doi.org/10.15414/ainhlq.2021.0018

Greater celandine (Chelidonium majus L., Papaveraceae) is a perennial herbaceous plant, with an upright and spreading stem, large leaves, and yellow flowers collected on the tops of the stems in rare umbel inflorescence. The main aim of the study was an assessment of the oxidative stress biomarkers [2-thiobarbituric acid reactive substances (TBARS), carbonyl derivatives content of protein oxidative modification (OMP), total antioxidant capacity (TAC)] and also activity of antioxidant enzymes (catalase, ceruloplasmin) in the equine plasma after treatment by extracts derived from roots and stems of $C$. majus collected from rural and urban agglomerations. Plant materials were collected from natural habitats on the territory of the Kartuzy district in the Pomeranian province (northern part of Poland). Our results demonstrated that statistically significant reductions in lipid peroxidation byproducts were noted after incubation with extracts derived from roots of C. majus collected from both urban (by $35 \%, \mathrm{p}<0.05$ ) and rural (by $34 \%, \mathrm{p}<0.05$ ) agglomerations compared to the control samples. Stem extracts derived from $C$. majus also reduced TBARS levels, but only extracts derived from $C$. majus were collected from the rural areas; a statistically significant decrease (by $21 \%, \mathrm{p}<0.05$ ) was observed compared to the control samples. The lowest values in the content of the aldehydic derivatives of OMP were observed after incubation with extracts derived from roots of $C$. majus collected from both rural and urban areas. On the other hand, levels of ketonic derivatives of OMP were significantly increased after incubation with extracts derived from stems of $C$. majus collected from both rural and urban areas compared to the control samples, in contrast to extracts derived from roots of $C$. majus collected from urban areas, where there was a statistically significant reduction in ketonic derivatives of OMP (by $15 \%$, $\mathrm{p}<0.05$ ) compared to the control samples. A significant increase in the TAC levels was observed after incubation with root and stem extracts of $C$. majus collected from both urban and rural areas, but the highest values were observed after incubation with extracts derived from roots of $C$. majus collected from rural areas (by $66.7 \%$, p <0.05) compared to the control samples. Stem extracts of $C$. majus collected from urban agglomerations were found to be most effective in increasing catalase activity (by $115 \%, \mathrm{p}<0.05$ ). Both root and stem extracts of $C$. majus collected from rural areas caused a statistically significant reduction in ceruloplasmin levels. These in vitro studies indicate that extracts from this plant are a significant source of natural antioxidants that could prevent the progression of various disorders caused by oxidative stress. However, the proportions of secondary metabolites responsible for the antioxidant activity of $C$. majus extracts are currently unclear. Therefore, further studies are needed to isolate and identify the antioxidant compounds present in the plant extracts. Screening of $C$. majus plant for other biological activities including antioxidant activities is essential and may be effective for searching the preventive agents in the pathogenesis of some metabolic diseases.

Keywords: Chelidonium majus, root and stem extracts, equine plasma, lipid peroxidation, oxidatively modified proteins, total antioxidant capacity, catalase, ceruloplasmin

\footnotetext{
*Corresponding Author: Halyna Tkachenko, Institute of Biology and Earth Sciences, Pomeranian University in Słupsk, Arciszewski Str. 22b, 76-200 Słupsk, Poland $\triangle$ tkachenko@apsl.edu.pl
} 


\section{Introduction}

Organismal life encounters reactive oxidants from internal metabolism and environmental toxicant exposure. Reactive oxygen and nitrogen species cause oxidative stress and are traditionally viewed as being harmful (Forrester et al., 2019). Reactive oxygen species (ROS) regulate cellular homeostasis and act as prime modulators of cellular dysfunction contributing to disease pathophysiology. ROS are byproducts of numerous enzymatic reactions in various cell compartments, including the cytoplasm, cell membrane, endoplasmic reticulum (ER), mitochondria, and peroxisome, as part of basal metabolic function (Allen and Bayraktutan, 2009; Goncharov et al., 2015; Forrester et al., 2019). Oxidative stress is now recognized to play a central role in the pathophysiology of many different disorders (Bedard and Krause, 2007).

Living cells are under constant oxidative attack from reactive oxygen species, which can cause, among other things, lipid peroxidation or increase the level of byproducts of excessive protein oxidation. The lipid peroxidation chain reactions products display high biological activity (Brieger et al., 2012; Paik et al., 2017). It destroys DNA, proteins, and enzyme activity as well as acts as a molecular to activate signaling pathways initiating cell death (Su et al., 2019). As proteins are highly abundant and react rapidly with many oxidants, they are highly susceptible to, and major targets of, oxidative damage. This can result in changes to protein structure, function, and turnover and loss or (occasional) gain of activity (del Río et al., 1992).

Accumulation of oxidatively-modified proteins, due to either increased generation or decreased removal, has been associated with both ageing and multiple diseases (Singh, 1996). Different oxidants generate a spectrum of broad, sometimes characteristic, post-translational modifications (Hawkings and Davies, 2019).

Equine erythrocytes are uniquely susceptible to oxidant-induced damage due to the use of inefficient mechanisms to correct and protect against oxidative damage (Harvey et al., 2003). Oxidants typically damage erythrocytes by oxidizing the heme iron in hemoglobin, reactive sulfhydryls, or unsaturated lipids in the membranes. The oxidation of the heme iron in hemoglobin to the ferric $\left(\mathrm{Fe}^{3+}\right)$ state generates methemoglobin, which is incapable of transporting oxygen (Baskurt and Meiselman, 1999; Boyer et al., 2002). Oxidation of sulfhydryl groups in the globin portion of hemoglobin can induce protein denaturation and the formation of Heinz body aggregates. The oxidation of sulfhydryl groups and unsaturated lipids can also compromise the erythrocyte membrane integrity (Wright et al., 1999). Reduced glutathione (GSH) can protect erythrocytes against oxidant injury, being oxidized itself to a disulfide; however, horses have a reduced ability to regenerate reduced GSH, compared with other mammals, likely due to the decreased activity of glutathione reductase in equine erythrocytes. Under normal conditions, equine erythrocytes have sufficient capacity to prevent oxidative damage (Robin and Harley, 1967; Medeiros et al., 1984).

A complex system of antioxidant defenses has evolved that generally holds this attack in balance. In recent years, an important increase in the attempts to find natural sources of molecules with biological potential has been noticed (Storz, 2005; Liou and Storz, 2010). Polyphenols from plants are such molecules, which have proven important antioxidant activity (Unuofin and Lebelo, 2020). Antioxidants are important agents involved in the protection against oxidative stress that has proven to be one of the most important causes of many diseases nowadays (Diniz do Nascimento et al., 2020). Therefore, in recent years, many researchers have focused on this direction, with important results in the curative or adjuvant treatment of some diseases (Ratnam et al., 2006; Pisoschi et al., 2016). Several medicinal plants have been proven to contain significant amounts of polyphenols, which added an important value to their use in the therapy of numerous diseases (Carocho and Ferreira, 2013).

Plants naturally produce many new metabolic compounds that have been an invaluable source of pharmacological discovery for centuries (Rahman, 2007). Plants, particularly those of the Papaveraceae family, produce many antioxidant factors including a wide range of natural defensive compounds such as phenols, terpenoids, alkaloids, polyacetylenes, lectins, and carotenoids (Păltinean et al., 2017). Chelidonium majus (CM) is a perennial herbaceous plant, with an upright and spreading stem, large leaves, and yellow flowers collected on the tops of the stems in rare umbel inflorescence. The plant is widely present in Europe and Asia, North America, and a part of Northwest Africa (Krahulcová, 1982). The plant contains, as major secondary metabolites, isoquinoline alkaloids, such as sanguinarine, chelidonine, chelerythrine, berberine, and coptisine. Other compounds structurally unrelated to the alkaloids have been isolated from the aerial parts: several flavonoids and phenolic acids (Colombo and Bosisio, 1996). Crude extracts of CM, as well as purified compounds derived from it, exhibit a broad spectrum of bioactive properties with a potential 
for the protection of human health, such as antiinflammatory, antimicrobial, cytotoxic, analgesic, antioxidant, antiulcer, acetylcholinesterase- and butyrylcholinesterase-inhibitory, and hepatoprotective activities (Lee et al., 2007; Kuenzel et al., 2013). The high spectrum of antioxidant properties for CM that are increasingly being used suggests the necessity of further investigations regarding their influence on organs and tissue function, including the evaluation of molecular mechanisms involved to exploit them for potential therapeutic benefits (Lenfeld et al., 1981; Kokoska et al., 2002; Havelek et al., 2016).

The originality of this work is that it is a study on the antioxidant activity of $\mathrm{CM}$ using equine blood as an adequate model. Furthermore, to increase the rationale for the possible introduction of greater celandine extracts into phytotherapy, the present study also evaluated the level of ceruloplasmin and catalase activity after dosing of the greater celandine extracts. However, with the advent of modern and synthetic drugs and supplements, many of these natural plant-derived antioxidant compounds have remained unexplored. This is the main reason why characterization and testing the biological activity of extracts obtained from this plant is essential for their introduction in therapy as phytopharmaceuticals.

Therefore, in the present study, the oxidative stress biomarkers [2-thiobarbituric acid reactive substances, carbonyl derivatives of oxidative modification of proteins, total antioxidant capacity], as well as activity of antioxidant enzymes (catalase, ceruloplasmin) in the equine plasma, were used for assessing the antioxidant activity of root and stem extracts derived from Chelidonium majus collected in urban and rural agglomerations of Kartuzy district in the Pomeranian province (northern part of Poland).

\section{Material and methodology}

\section{Collection of plant material}

The plants of Chelidonium majus were harvested from natural habitats on the territory of the Kartuzy district

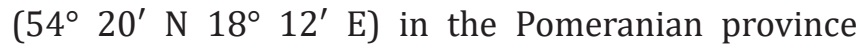
(northern part of Poland) (Figure 1A). Kartuzy is located about 32 kilometers (20 miles) west of Gdańsk and $35 \mathrm{~km}$ (22 miles) south-east of the town of Lębork on a plateau at an altitude of approximately 200 meters (656 feet) above sea level on average. The plateau, which is divided by the Radaune lake, comprises the highest parts of the Baltic Sea Plate (http://www.kartuzy.pl/). Plants were collected from urban $(n=5)$ and rural agglomerations $(n=15)$ on the territory of the Kartuzy district.

\section{Preparation of plant extracts}

Freshly collected roots and stems were washed, weighed, crushed, and homogenized in $0.1 \mathrm{M}$ phosphate buffer ( $\mathrm{pH}$ 7.4) (in proportion $1: 19, \mathrm{w} / \mathrm{w}$ ) at room temperature. The extracts were then filtered and used for analysis. The extracts were stored at $-20{ }^{\circ} \mathrm{C}$ until use.

\section{Horses}

Eighteen healthy adult horses from the central Pomeranian region in Poland (village Strzelinko, $\mathrm{N} 54^{\circ} 30^{\prime} 48.0^{\prime \prime}$ E $16^{\circ} 57^{\prime} 44.9^{\prime \prime}$ ), aged $8.9 \pm 1.3$ years

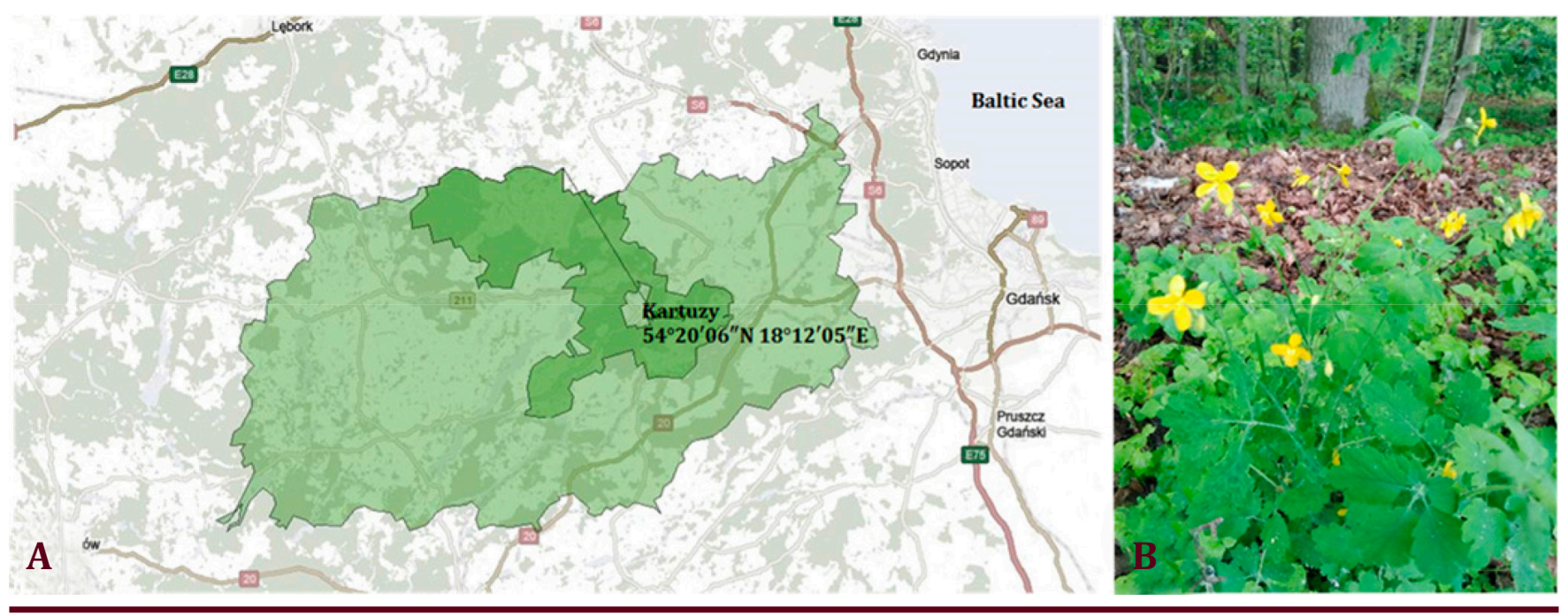

Figure 1 Location of Kartuzy in the map of northern Poland (A), where the greater celandine (B) was collected (Photo by Nataniel Stefanowski) 
old, including 6 Hucul pony, 5 Thoroughbred horses, 2 Anglo-Arabian horses, and 5 horses of unknown breed, were used in this study. All horses participated in recreational horseback riding. Horses were housed in individual boxes, with feeding (hay and oat) provided twice a day, at 08.00 and $18.00 \mathrm{~h}$, and water available $\mathrm{ad}$ libitum. All horses were thoroughly examined clinically and screened for hematological, biochemical, and vital parameters, which were within reference ranges. The females were non-pregnant.

\section{Collection of blood samples}

Blood was drawn from the jugular vein of the animals in the morning, 90 minutes after feeding, while the horses were in the stables (between 8:30 and 10 AM). Blood was stored in tubes with sodium citrate as the anticoagulant and held on the ice until centrifugation at 3,000 rpm for $5 \mathrm{~min}$ to remove plasma. The pellet of blood was re-suspended in $4 \mathrm{mM}$ phosphate buffer $\mathrm{pH}$ 7.4). A volume of $0.1 \mathrm{~mL}$ of the plant extract was added to $1.9 \mathrm{~mL}$ of equine plasma. For positive control, $4 \mathrm{mM}$ phosphate buffer ( $\mathrm{pH}$ 7.4) was used. After incubating the mixture at $37{ }^{\circ} \mathrm{C}$ for $60 \mathrm{~min}$ with continuous stirring, it was centrifuged at 3,000 rpm for $5 \mathrm{~min}$. Plasma aliquots were used in the study.

\section{The 2-Thiobarbituric acid reactive substances (TBARS) assay}

The level of lipid peroxidation was determined by quantifying the concentration of 2-thiobarbituric acid reacting substances (TBARS) with the Kamyshnikov (2004) method for determining the malonic dialdehyde (MDA) concentration. This method is based on the reaction of the degradation of the lipid peroxidation product, MDA, with TBA under high temperature and acidity to generate a colored adduct that is measured spectrophotometrically. The nmol of MDA per $\mathrm{mL}$ was calculated using $1.56 \cdot 10^{5} \mathrm{mM} / \mathrm{cm}$ as the extinction coefficient.

\section{The carbonyl derivatives content of protein oxidative modification (OMP) assay}

To evaluate the protective effects of extracts derived from root and stem extracts derived from CM collected from urban and rural agglomerations against free radical-induced protein damage in equine erythrocytes and plasma, a content of carbonyl derivatives of protein oxidative modification (OMP) assay based on the spectrophotometric measurement of aldehydic and ketonic derivatives in the plasma was performed. The rate of protein oxidative destruction was estimated from the reaction of the resultant carbonyl derivatives of amino acid reaction with 2,4-dinitrophenylhydrazine (DNFH) as described by Levine and co-workers (1990) and as modified by Dubinina and co-workers (1995). DNFH was used for determining carbonyl content in soluble and insoluble proteins. Carbonyl groups were determined spectrophotometrically from the difference in absorbance at $370 \mathrm{~nm}$ (aldehydic derivatives, $\mathrm{OMP}_{370}$ ) and $430 \mathrm{~nm}$ (ketonic derivatives, $\mathrm{OMP}_{430}$ ).

\section{Measurement of total antioxidant capacity (TAC)}

The TAC level in the sample was estimated by measuring the 2-thiobarbituric acid reactive substances (TBARS) level after Tween 80 oxidation. This level was determined spectrophotometrically at $532 \mathrm{~nm}$ (Galaktionova et al., 1998). Sample inhibits the $\mathrm{Fe}^{2+} /$ ascorbate-induced oxidation of Tween 80 , resulting in a decrease in the TBARS level. The level of TAC in the sample (\%) was calculated relatively the absorbance of the blank sample.

\section{Assay of catalase activity}

Catalase (CAT, E.C. 1.11.1.6) activity was determined by measuring the decrease of $\mathrm{H}_{2} \mathrm{O}_{2}$ in the reaction mixture using a spectrophotometer at the wavelength of $410 \mathrm{~nm}$ by the method of Koroliuk et al. (1988). One unit of catalase activity is defined as the amount of enzyme required for decomposition of $1 \mu \mathrm{mol} \mathrm{H}_{2} \mathrm{O}_{2}$ per min per $\mathrm{mL}$ of blood.

\section{Assay of Ceruloplasmin level}

The ceruloplasmin (CP, EC 1.16.3.1) level in the plasma was measured spectrophotometrically at $540 \mathrm{~nm}$, as described by Ravin (1961). The assay mixture contained $0.1 \mathrm{~mL}$ of plasma, $0.4 \mathrm{M}$ sodium acetate buffer ( $\mathrm{pH}$ 5.5), and $0.5 \% p$-phenylenediamine. The mixture was incubated at $37{ }^{\circ} \mathrm{C}$ for $60 \mathrm{~min}$. Before cooling at $4{ }^{\circ} \mathrm{C}$ for $30 \mathrm{~min}$, the mixture was added to $3 \%$ sodium fluoride for inhibition. Ceruloplasmin was expressed in mg per dL of plasma.

\section{Statistical analysis}

The arithmetic means \pm S.E.M. values were calculated for each group to determine the significance of the intergroup difference. All variables were tested for normal distribution using the Kolmogorov-Smirnov and Lilliefors test ( $p>0.05)$. The significance of differences between the levels of oxidative stress biomarkers (significance level, $\mathrm{p}<0.05$ ) was examined using the Mann-Whitney $U$ test (Zar, 1999). All statistical calculation was performed on separate data from 
each individual with Statistica 13.3 software (StatSoft, Krakow, Poland).

\section{Results and discussion}

The cellular components, that make up the cell membrane, the most exposed to the harmful action of free radicals are lipid structures, lipoproteins, and proteins. Damage of the abundant and thus most susceptible polyunsaturated fatty acid (PUFA) is termed lipid peroxidation (Srivastava and Shrivastava, 2016). The most widely used assay for lipid peroxidation is malonic dialdehyde (MDA) formation as a secondary lipid peroxidation product, with the 2-thiobarbituric acid reactive substances test (Xiong et al., 2020).

Protein oxidation reactions involve, among others, ROS free radicals and result in oxidative modification of amino acid side chains, peptide cleavage under the influence of reactive oxygen species, reactions of peptides with lipids and products of carbohydrate oxidation, and formation of carbonyl derivatives of proteins (Himmelfarb et al., 2000).

Figure 2 shows the TBARS levels obtained by incubating equine plasma in the presence of aqueous extracts derived from the root and stem of CM collected from rural and urban agglomerations. Statistically significant reductions in levels of lipid peroxidation byproducts were noted after incubation with root extracts of CM collected from both urban (by $35 \%, \mathrm{p}<0.05$ ) and rural (by $34 \%, p>0.05$ ) agglomerations compared to the control samples. Stem extracts derived from CM also reduced TBARS levels, but only those collected in rural areas; there was a statistically significant decrease by $21 \%(\mathrm{p}<0.05)$.

The aldehydic and ketonic derivatives of oxidatively modified proteins in the equine plasma after in vitro incubation with root and stem extracts derived from C. majus collected from rural and urban areas of Pomeranian region were present in Figure 3.

A similar result (Figure 3) was observed in the levels of aldehydic derivatives of oxidatively modified proteins, where the lowest value was observed after incubation with extracts derived from roots of CM collected from both rural and urban areas (by 7 and $8 \%$, respectively, $\mathrm{p}>0.05$ ) compared to the control samples. On the other hand, levels of ketonic derivatives of OMP showed that stem extracts of CM collected from both urban and rural areas, significantly increased levels of protein oxidation compared to the control samples (by 16 and $17 \%$, respectively, $\mathrm{p}>0.05$ ) in contrast to root extracts of CM collected from urban areas, where there was a statistically significant reduction in ketonic derivatives of oxidatively modified proteins by $15 \%$ $(p<0.05)$ compared to the control samples.

Measurement of total antioxidant capacity (Figure 4) after incubation with CM extracts showed surprising results. Statistically significant increases in TAC levels were observed after incubation with root and stem extracts of CM collected from both urban and rural

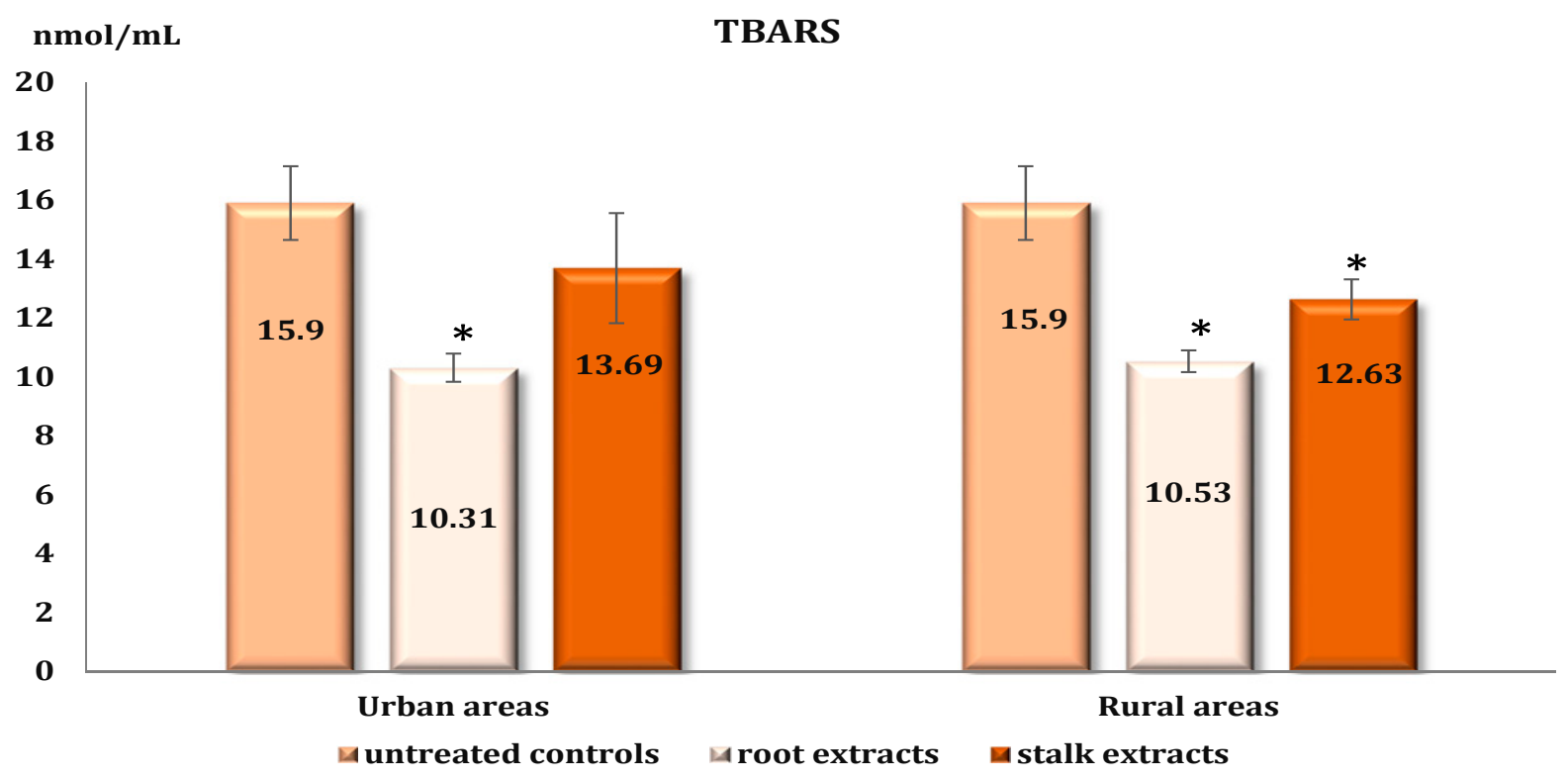

Figure 2 The TBARS content as a biomarker of lipid peroxidation in the equine plasma after in vitro incubation with root and stem extracts obtained from Chelidonium majus L. collected from rural and urban areas of Pomeranian region $(\mathrm{M} \pm \mathrm{m}, \mathrm{n}=8)$

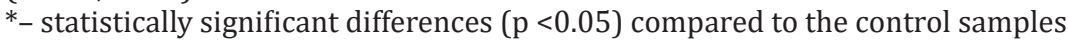



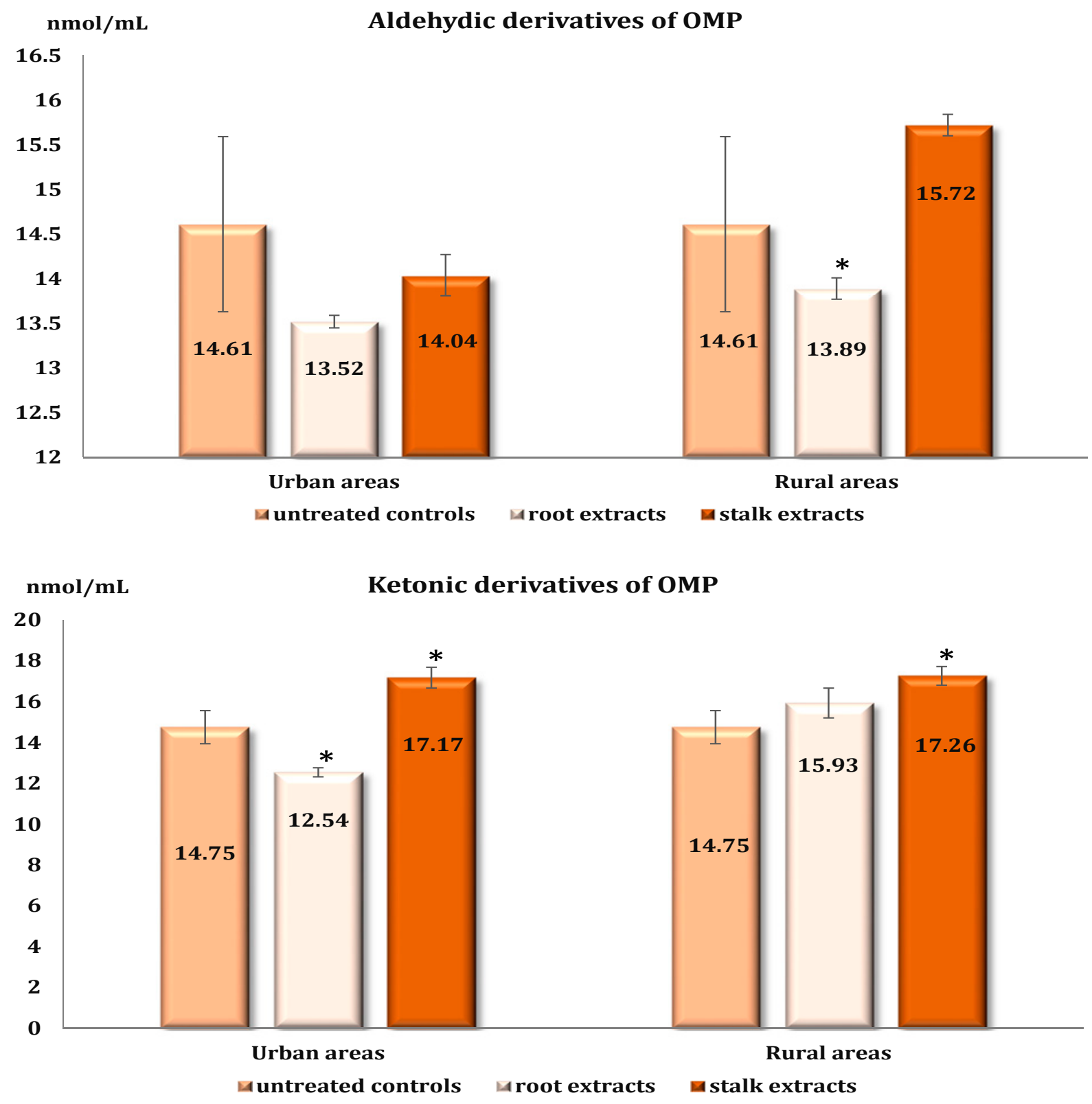

Figure 3 The aldehydic and ketonic derivatives of oxidatively modified proteins in the equine plasma after in vitro incubation with root and stem extracts obtained from Chelidonium majus L. collected from rural and urban areas of Pomeranian region $(M \pm m, n=8)$

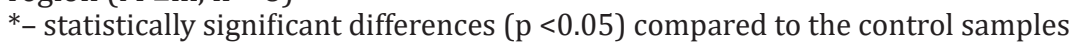

areas. Moreover, the highest value was observed after incubation with root extracts of $C$. majus collected from rural areas (increase by $67 \%, \mathrm{p}<0.05$ compared to the control samples).

Antioxidants are substances that prevent the oxidation of other compounds. Enzymatic antioxidants consist of superoxide dismutase and catalase. The enzymatic antioxidants have more effective protective effects against active and massive oxidative attacks due to the ability to decompose ROS (He et al., 2017). Therefore, this set of antioxidants play important role in diseases prevention. Catalase (CAT), is among the most important antioxidant enzyme against hydrogen peroxides (Muhlisin et al., 2016). In our study, stem extracts of CM collected from urban agglomerations were found to be most effective in increasing catalase activity (by $115 \%, \mathrm{p}<0.05$ ) (Figure 5). Root extracts of CM collected from rural agglomerations also significantly increased catalase levels by $65 \%(\mathrm{p}<0.05)$. Probably, the increase in catalase activity has resulted in a $65 \%$ increase in TAC level $(p<0.05)$ (Figure 4). 


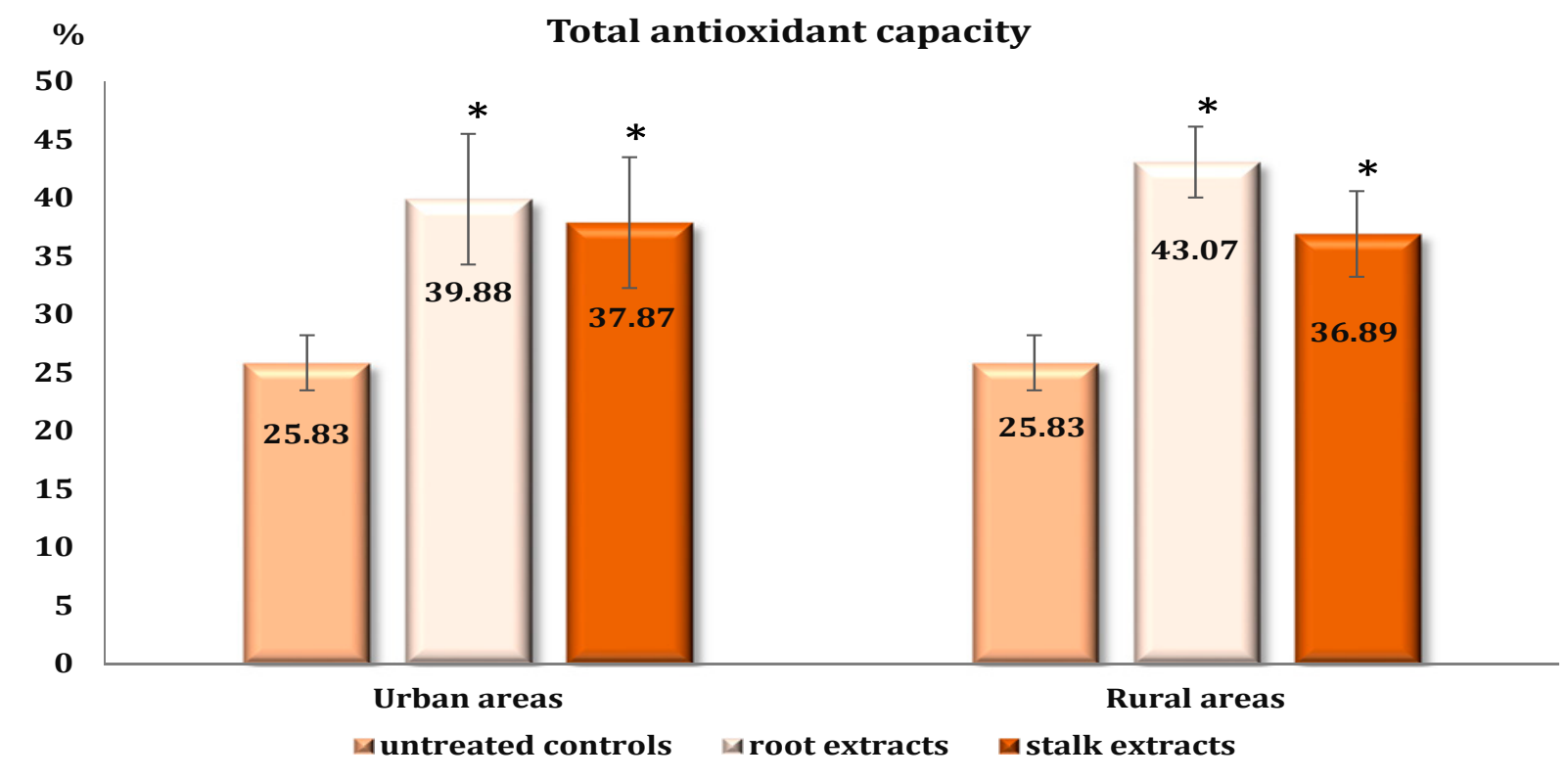

Figure 4 The total antioxidant capacity in the equine plasma after in vitro incubation with root and stem extracts obtained from Chelidonium majus L. collected from rural and urban areas of Pomeranian region $(\mathrm{M} \pm \mathrm{m}, \mathrm{n}=8)$

*_statistically significant differences $(\mathrm{p}<0.05)$ compared to the control samples

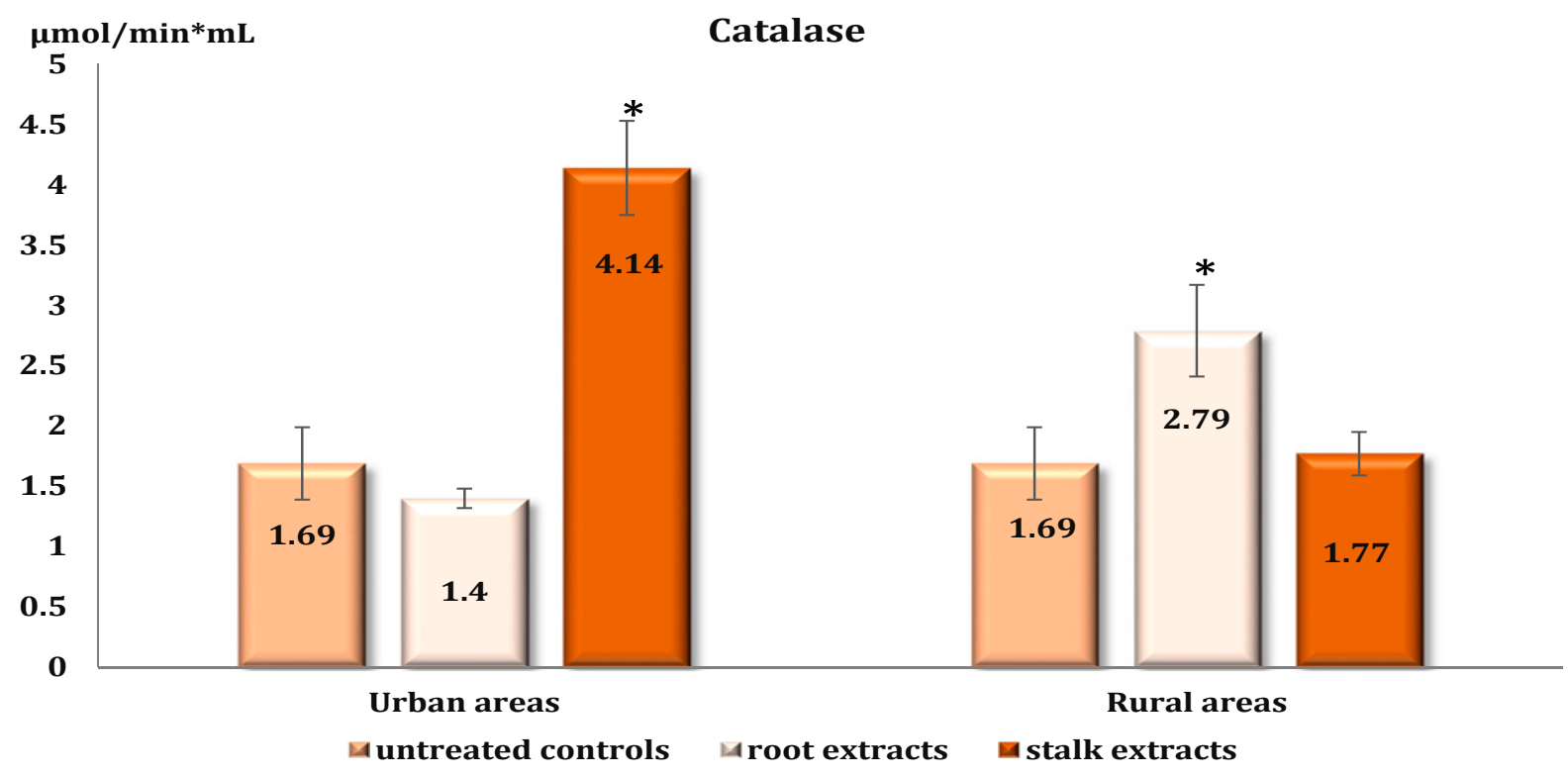

Figure 5 The catalase activity in the equine plasma after in vitro incubation with root and stem extracts obtained from Chelidonium majus L. collected from rural and urban areas of Pomeranian region $(\mathrm{M} \pm \mathrm{m}, \mathrm{n}=8)$

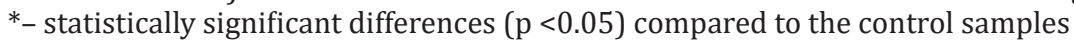

Ceruloplasmin (CP) is a copper-binding glycoprotein that is the major ferroxidase in liver-derived plasma (Arenas de Larriva et al., 2020). It is characterized as a copper $(\mathrm{Cu})$-containing protein that binds $40-70 \%$ of the $\mathrm{Cu}$ in plasma and is mainly produced by the liver. This protein is a member of the multicopper oxidase family, an evolutionarily conserved group of proteins that use copper to couple substrate oxidation with the four-electron reduction of oxygen to water (Jeremy and Shukla, 2014). Apart from playing a role in copper and iron metabolism, CP is an acute-phase reactant that may work as an antioxidant but can also generate free radicals that may lead to several illnesses (Dadu et al., 2013). In our study, root and stem extracts of 


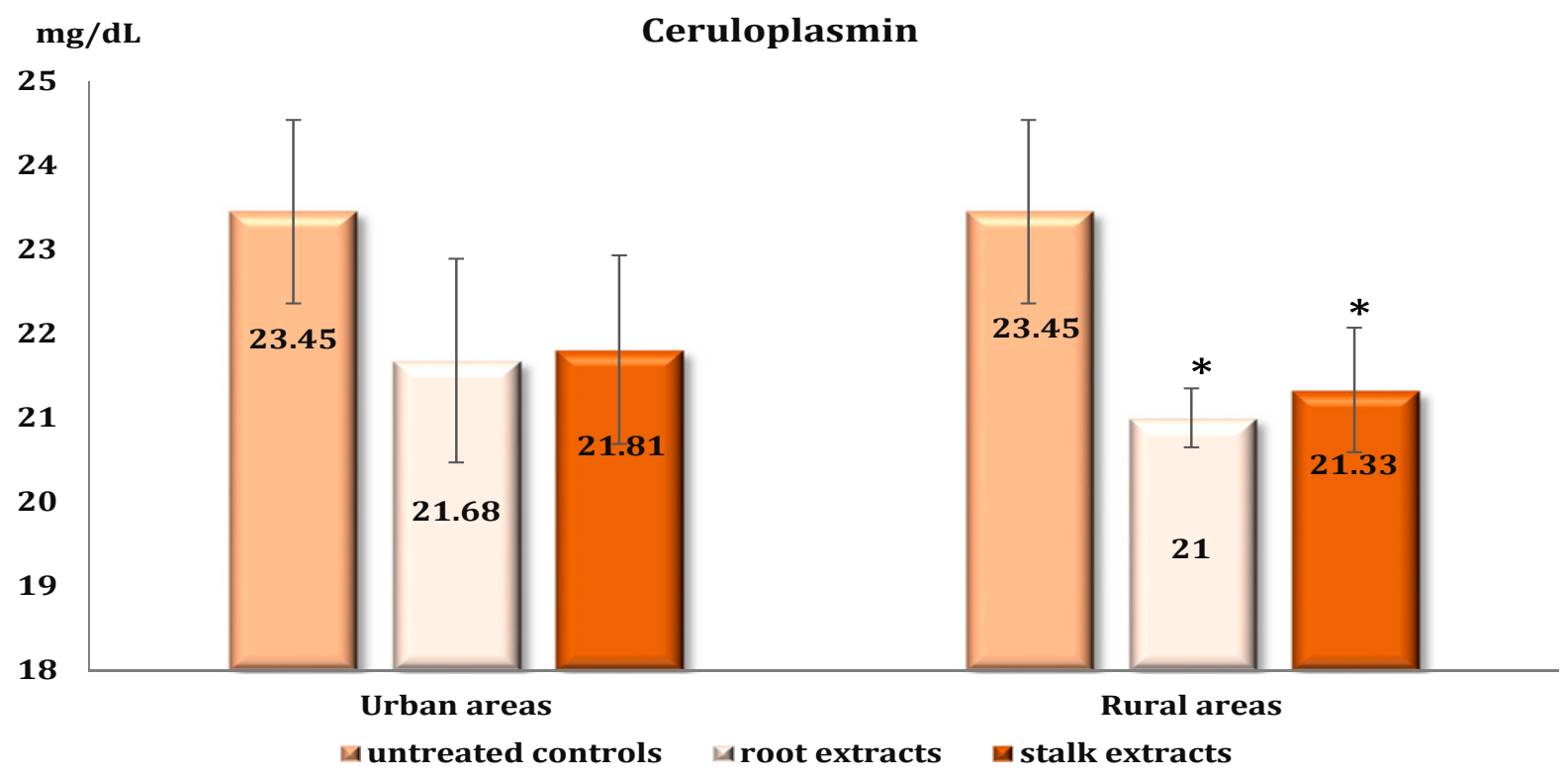

Figure 6 The ceruloplasmin level in the equine plasma after in vitro incubation with root and stem extracts obtained from Chelidonium majus L. collected from rural and urban areas of Pomeranian region $(\mathrm{M} \pm \mathrm{m}, \mathrm{n}=8)$

*- statistically significant differences $(\mathrm{p}<0.05)$ compared to the control samples

CM collected from rural areas caused a statistically significant reduction in ceruloplasmin levels by 10 and $9 \%$, respectively $(\mathrm{p}<0.05)$ (Figure 6).

In the current study, we investigated the effects of $\mathrm{CM}$ extracts on lipid peroxidation and biomarkers of oxidatively modified proteins, as well as on antioxidant defense in equine plasma. Our study suggests that the crude extracts obtained from CM roots exhibit effective antioxidant activity when incubated with equine plasma. The protective effect of CM extracts is evident from the improvement of antioxidant enzymes activity exemplified by catalase and increase in total antioxidant capacity. The antioxidant defense system was improved with the suppression of aldehydic and ketonic derivatives of oxidatively modified proteins after incubation with $\mathrm{CM}$ extracts. CM extracts have also shown anti-inflammatory activity expressed by decreasing plasma ceruloplasmin levels.

In our previous study (Stefanowski et al., 2021a, b) on muscle tissue of rainbow trout (Oncorhynchus mykiss Walbum), we also demonstrated the antioxidant activity of CM extracts. Our results showed that extracts of CM collected from both urban and rural areas statistically significantly reduced the level of aldehydic derivatives of OMB by $18.8 \%(p<0.05)$. The analysis of the levels of ketonic derivatives of OMP showed that extracts of CM collected from both urban and rural areas statistically significantly decreased the level of ketonic derivatives of OMP by 20.6 and $21.5 \%$, respectively (for urban areas), as well as 26.7 and $12.5 \%$ (for rural areas). Lower levels of lipid peroxidation were observed after incubation with stem extracts, while those collected from rural areas showed the lowest result (by $11 \%$ ). Root extracts of CM collected from urban and rural areas increased TBARS levels. Analysis of oxidatively modified protein in the blood of rainbow trout after in vitro incubation with root and stem extracts showed that extracts can inhibit the production of oxidative carbonyls by scavenging free radicals.

Phytochemical constituents in the Papaveraceae family are known to be biologically active compounds and they are responsible for different activities such as antioxidant, antimicrobial, antifungal, and anticancer (Zielińska et al., 2018). CM contains, as major constituents, isoquinoline alkaloids (such as sanguinarine, chelidonine, chelerythrine, berberine, protopine, and coptisine), flavonoids, and phenolic acids (Gilca et al., 2010). Both crude extracts of CM and purified compounds derived from it exhibit a wide variety of biological activities (anti-inflammatory, antimicrobial, immunomodulatory, antitumoral, choleretic, hepatoprotective, analgesic, etc.) which are in concordance with the traditional uses of CM (Gilca et al., 2010; Zielińska et al., 2018).

Phenols are a large class of secondary metabolites. Phenolics (including flavonoids) are among the most active antioxidants, as well as the most important stabilization factors of the oxidative processes. 
Flavonoids include many pharmacological and biological properties. In phytopharmacy, flavonoids are the active ingredients, of plant origin, with strong biological effects, while in dietetics and food industries they present important phytonutrients, preservatives, spices, and aromatics substances (Stanković et al., 2010, 2011; Jakovljevic et al., 2013). The highest concentration of total phenolic compounds was observed by Jakovljevic et al. (2013) in the spring when the CM was in the rosette stage with well-formed, thick leaves, but when the whole plant is not yet sufficiently developed. When the plant enters the flowering stage, there is a lack of that concentration, which again increases when the plant begins with the formation of fruit. The concentration of flavonoids is the greatest just before flowering and before fruiting. During flowering, the concentrations of these secondary metabolites are the lowest. The antioxidant activity and total phenol concentrations are the highest in the spring months during the rosette stage (Jakovljevic et al., 2013).

Neither strong nor direct relations were found between the antioxidant activity of the plant and the concentrations of flavonoid content and phenolic compounds. This could be due to the complexity of the substances which cause the antioxidant activity of this plant. The composition evolution in two opposite ways simultaneously for two compounds characterized by high individual activities could lead to the compensatory effect of the final activity (Gourine et al., 2010; Jakovljevic et al., 2013).

The analysis conducted by Nawrot et al. (2016) confirmed the presence of the protein components of the antioxidant defense system in the CM latex. These proteins form the first line of defense against different stress conditions and help to prevent the attack of different pathogens, which are highly abundant in the milky sap. Peroxidase 12-like and isoflavone reductase homolog were present only in the milky sap. The presence of class III plant peroxidase, glyoxalase, quinone reductase, and ubiquitin in CM latex was previously reported by Nawrot et al. (2007a, b).

Lee et al. (2007) in animal studies showed, that CM methanol extract significantly suppressed the progression of collagen-induced arthritis in mice. This action was characterized by a decreased production of TNF- $\alpha$, IL-6, Interferon(IFN)- $\gamma$, B cells, $\gamma \delta$-T cells (in spleen), and an increased proportion of CD4+CD25+ regulatory T cells. The serum levels of IgG and IgM RA factors were decreased. Song et al. (2002) in in vitro studies showed an interesting immunomodulatory potential exhibited by a protein-bound polysaccharide extracted from C. majus (CM-Ala), which showed mitogenic activity on spleen cells, bone marrow cells, and increased the number of granulocyte macrophagecolony forming cells (GM-CFC). When CM extract was used in combination with recombinant IFN- $\gamma$, there was a marked combined induction of NO and TNF- $\alpha$ production in mouse peritoneal macrophages.

Plants are an important origin of natural substances that are the raw material for various pharmaceutical and therapeutic applications due to the presence of phytochemicals, such as alkaloids. Alkaloids, which are found in different plant species, possess numerous biological activities. Some alkaloids have strong cytotoxic effects on various cancer cells (Deljanin et al., 2016). The CM root has higher all determined alkaloid contents as compared to extract that is obtained from herb (Petruczynik et al., 2019). The highest contents of chelerythrine, sanguinarine, and berberine possessing very high cytotoxic activity were found in the root extract. These isoquinoline alkaloids might have synergistic high cytotoxic activity on cancer cell lines. Extracts that were obtained from CM exhibit very strong cytotoxicity (Zielińska et al., 2020). The studies of Petruczynik and co-workers (2019) indicated the strong cytotoxicity of these extracts against Pancreatic Cell Lines (PANC-1, IC ${ }_{50}, 20.7 \mu \mathrm{g} / \mathrm{mL}$ ) and Cell Line human Caucasian colon adenocarcinoma grade II (HT$29, \mathrm{IC}_{50}, 20.6 \mu \mathrm{g} / \mathrm{mL}$ ), and moderate cytotoxic activity against Cell Line human breast adenocarcinoma (MDA-MB-231, $\mathrm{IC}_{50}, 73.9 \mu \mathrm{g} / \mathrm{mL}$ ), Cell Line human from human lung (carcinoma, A-549), HeLa, and Cellosaurus cell line SGC-7901 cell lines. Their studies have shown that the extracts from $\mathrm{CM}$ are also cytotoxic against other cell lines (FaDu, SCC-25, MCF-7, MDA-MB-231, and CRL1634). FaDu and SCC-25 cell lines belong to the so-called head and neck squamous cell carcinomas are often resistant to chemotherapy, even including targeted drug therapy.

\section{Conclusions}

The results showed that the extracts obtained from the roots and stems of $C$. majus exhibited effective antioxidant activity when incubated with equine plasma. The protective effect of CM root extracts is evident from the improvement of antioxidant defenses and increase in total antioxidant capacity. The antioxidant defense system was improved with the suppression of aldehydic and ketonic derivatives of oxidatively modified proteins after incubation with root and stem extracts. CM extracts have shown anti-inflammatory activity expressed as a decrease in plasma ceruloplasmin levels. The pronounced effect 
of $\mathrm{CM}$ root extract can be attributed to the secondary metabolites it contains, such as polyphenols and flavonoids. Finally, further studies are needed to reveal the exact cellular mechanisms of the effects of $\mathrm{CM}$ extract on erythrocyte and plasma function. These in vitro studies indicate that extracts from this plant are a significant source of natural antioxidants that could prevent the progression of oxidative stress. However, the proportions of secondary metabolites responsible for the antioxidant activity of CM extracts are currently unclear. Therefore, further studies are needed to isolate and identify the antioxidant compounds present in the plant extracts.

\section{References}

Allen, C.L., \& Bayraktutan, U. (2009). Oxidative stress and its role in the pathogenesis of ischaemic stroke. Int. J. Stroke, 4(6), 461-470. https://doi.org/10.1111/j.1747-4949.2009.00387.x

Arenas De Larriva, A.P., Limia-Pérez, L., Alcalá-Díaz, J.F., Alonso, A., López-Miranda, J., \& Delgado-Lista, J. (2020). Ceruloplasmin and Coronary Heart Disease-A Systematic Review. Nutrients, 12(10), 3219. https://doi.org/10.3390/nu12103219

Baskurt, O.K., \& Meiselman, H.J. (1999). Susceptibility of equine erythrocytes to oxidant-induced rheologic alterations. Am. J. Vet. Res., 60(10), 1301-1306.

Bedard, K., \& Krause, K.H. (2007). The NOX family of ROS-generating NADPH oxidases: physiology and pathophysiology. Physiol. Rev., 87(1), 245-313. https://doi.org/10.1152/physrev.00044.2005

Boyer, J.D., Breeden, D.C., \& Brown, D.L. (2002). Isolation, identification, and characterization of compounds from Acer rubrum capable of oxidizing equine erythrocytes. Am. J. Vet. Res., 63(4), 604-610. https://doi.org/10.2460/ajvr.2002.63.604

Brieger, K., Schiavone, S., Miller, F.J. Jr., \& Krause, K.H. (2012). Reactive oxygen species: from health to disease. Swiss Med. Wkly., 142, w13659.

https://doi.org/10.4414/smw.2012.13659

Carocho, M., \& Ferreira, I.C. (2013). A review on antioxidants, prooxidants and related controversy: natural and synthetic compounds, screening and analysis methodologies and future perspectives. Food Chem. Toxicol., 51, 15-25. https://doi.org/10.1016/j.fct.2012.09.021

Colombo, M.L., \& Bosisio, E. (1996). Pharmacological activities of Chelidonium majus L. (Papaveraceae). Pharmacol. Res., 33(2), 127-134.

https://doi.org/10.1006/phrs.1996.0019

Dadu, R.T., Dodge, R., Nambi, V., Virani, S.S., Hoogeveen, R.C., Smith, N.L., Chen, F., Pankow, J.S., Guild, C., Tang, W.H., Boerwinkle, E., Hazen, S.L., \& Ballantyne, C.M. (2013). Ceruloplasmin and heart failure in the atherosclerosis risk in communities study. Circ. Heart Fail, 6(5), 936-943.

https://doi.org/10.1161/CIRCHEARTFAILURE.113.000270
Del Río, L.A., Sandalio, L.M., Palma, J.M., Bueno, P., \& Corpas, F.J. (1992). Metabolism of oxygen radicals in peroxisomes and cellular implications. Free Radic. Biol. Med., 13(5), 557-580. https://doi.org/10.1016/0891-5849(92)90150-f

Deljanin, M., Nikolic, M., Baskic, D., Todorovic, D., Djurdjevic, P., Zaric, M., Stankovic, M., Todorovic, M., Avramovic, D., \& Popovic, S. (2016). Chelidonium majus crude extract inhibits migration and induces cell cycle arrest and apoptosis in tumor cell lines. J. Ethnopharmacol, 190, 362-371. https://doi.org/10.1016/i.jep.2016.06.056

Diniz Do Nascimento, L., Moraes, A.A.B., Costa, K.S.D., Pereira Galúcio, J.M., Taube, P.S., Costa, C.M.L., Neves Cruz, J., De Aguiar Andrade, E.H., \& Faria, L.J.G. (2020). Bioactive natural compounds and antioxidant activity of essential oils from spice plants: New findings and potential applications. Biomolecules, 10(7), 988.

https://doi.org/10.3390/biom10070988

Dubinina, E.E., Burmistrov, S.O., Khodov, D.A., \& Porotov, I.G. (1995). Okislitel'naia modifikatsiia belkov syvorotki krovi cheloveka, metod ee opredeleniia [Oxidative modification of human serum proteins. A method of determining it]. Vopr. Med. Khim., 41(1), 24-26. [In Russian]

Forrester, S.J., Kikuchi, D.S., Hernandes, M.S., Xu, Q., \& Griendling, K.K. (2018). Reactive Oxygen Species in Metabolic and Inflammatory Signaling. Circ. Res., 122(6), 877-902. https://doi.org/10.1161/CIRCRESAHA.117.311401

Galaktionova, L.P., Molchanov, A.V., El'chaninova, S.A., \& Varshavskiı̆, B. (1998). Lipid peroxidation in patients with gastric and duodenal ulcers. Klinicheskaia Labaratornaia Diagnostika, 6, 10-14.

Gilca, M., Gaman, L., Panait, E., Stoian, I., \& Atanasiu, V. (2010). Chelidonium majus - an integrative review: traditional knowledge versus modern findings. Forsch. Komplementmed, 17(5), 241-248. https://doi.org/10.1159/000321397

Goncharov, N.V., Avdonin, P.V., Nadeev, A.D., Zharkikh, I.L., \& Jenkins, R.O. (2015). Reactive oxygen species in pathogenesis of atherosclerosis. Curr. Pharm. Des., 21(9), 1134-1146.

https://doi.org/10.2174/1381612820666141014142557

Gourine, N., Yousfi, M., Bombarda, I., Nadjemi, B., \& Gaydou, E. (2010). Seasonal variation of chemical composition and antioxidant activity of essential oil from Pistacia atlantica Desf. leaves. J. Am. Oil Chem. Soc., 87, 157-166.

Harvey, J.W., Stockham, S.L., Scott, M.A., Johnson, P.J., Donald, J.J., \& Chandler, C.J. (2003). Methemoglobinemia and eccentrocytosis in equine erythrocyte flavin adenine dinucleotide deficiency. Vet. Pathol., 40(6), 632-642. https://doi.org/10.1354/vp.40-6-632

Havelek, R., Seifrtova, M., Kralovec, K., Habartova, K., Cahlikova, L., \& Rezacova, M. (2016). Chelidonine and homochelidonine induce cell death through cell cycle checkpoints and MAP kinase pathways. Nat. Prod. Commun., 12, 1419-1430. 
Hawkins, C.L., \& Davies, M.J. (2019). Detection, identification, and quantification of oxidative protein modifications. J. Biol. Chem., 294(51), 19683-19708. https://doi.org/10.1074/jbc. REV119.006217

He, L., He, T., Farrar, S., Ji, L., Liu, T., \& Ma, X. (2017). Antioxidants Maintain Cellular Redox Homeostasis by Elimination of Reactive Oxygen Species. Cell Physiol. Biochem., 44(2), 532-553. https://doi.org/10.1159/000485089

Himmelfarb, J., Mcmonagle, E., \& Mcmenamin, E. (2000). Plasma protein thiol oxidation and carbonyl formation in chronic renal failure. Kidney Int., 58(6), 2571-2578. https://doi.org/10.1046/j.1523-1755.2000.00443.x

Jakovljevic, Z.D., Stankovic, S.M., \& Topuzovic, D.M. (2013). Seasonal variability of Chelidonium majus L. secondary metabolites content and antioxidant activity. EXCLI J., $12,260-268$.

Jeremy, J.Y., \& Shukla, N. (2014). Ceruloplasmin dysfunction: a key factor in the pathophysiology of atrial fibrillation? J. Intern. Med., 275(2), 191-194. https://doi.org/10.1111/joim.12156

Kamyshnikov, V.S. (2004). A reference book on the clinic and biochemical researches and laboratory diagnostics. MEDpress-inform, Moscow.

Kokoska, L., Polesny, Z., Rada, V., Nepovim, A., \& Vanek, T. (2002). Screening of some Siberian medicinal plants for antimicrobial activity. J. Ethnopharmacol, 82(1), 51-53.

Koroliuk, M.A., Ivanova, L.I., Maĭorova, I.G., \& Tokarev, V.E. (1988). Metod opredeleniia aktivnosti katalazy [A method of determining catalase activity]. Lab. Delo, 1, 16-19. [In Russian]

Krahulcová, A. (1982). Cytotaxonomic Study of Chelidonium majus L. s. l. Folia Geobot. Phytotax., 17, 238-270.

Kuenzel, J., Geisler, K., Strahl, O., Grundtner, P., Beckmann, M.W., \& Dittrich, R. (2013). Chelidonium majus and its effects on uterine contractility in a perfusion model. Eur. J. Obstet. Gynecol. Reprod. Biol., 169(2), 213-217.

Lee, Y.C., Kim, S.H., Roh, S.S., Choi, H.Y., \& Seo, Y.B. (2007). Suppressive effects of Chelidonium majus methanol extract in knee joint, regional lymph nodes, and spleen on collagen-induced arthritis in mice. J. Ethnopharmacol, 112(1), 40-48.

Lenfeld, J., Kroutil, M., Marsálek, E., Slavík, J., Preininger, V., \& Simánek, V. (1981). Antiinflammatory activity of quaternary benzophenanthridine alkaloids from Chelidonium majus. Planta Med., 43(2), 161-165.

Levine, R.L., Garland, D., Oliver, C.N., Amici, A., Climent, I., Lenz, A.G., Ahn, B.W., Shaltiel, S., \& Stadtman, E.R. (1990). Determination of carbonyl content in oxidatively modified proteins. Methods Enzymol., 186, 464-478. http://dx.doi.org/10.1016/0076-6879(90)86141-h

Liou, G.Y., Storz, P. (2010). Reactive oxygen species in cancer. Free Radic. Res., 44(5), 479-496. https://doi.org/10.3109/10715761003667554

Medeiros, L.O., Nürmberger, R.Jr, \& Medeiros, L.F. (1984). The special behavior of equine erythrocytes connected with the methemoglobin regulation. Comp. Biochem. Physiol. $B, 78(4), 869-871$. https://doi.org/10.1016/0305-0491(84)90201-3

Muhlisin Utama, D.T., Lee, J.H., Choi, J.H., \& Lee, S.K. (2016). Antioxidant enzyme activity, iron content and lipid oxidation of raw and cooked meat of Korean native chickens and other poultry. Asian Australas. J. Anim. Sci., 29, 695-701.

Nawrot, R., Barylski, J., Lippmann, R., Altschmied, L., \& Mock, H.P. (2016). Combination of transcriptomic and proteomic approaches helps to unravel the protein composition of Chelidonium majus L. milky sap. Planta, 244(5), 1055-1064. https://doi.org/10.1007/s00425-016-2566-7

Nawrot, R., Kalinowski, A., \& Gozdzicka-Jozefiak, A. (2007a). Proteomic analysis of Chelidonium majus milky sap using two-dimensional gel electrophoresis and tandem mass spectrometry. Phytochemistry, 68, 1612-1622. https://doi.org/10.1016/j.phytochem.2007.03.039

Nawrot, R., Lesniewicz, K., Pienkowska, J., \& GozdzickaJozefiak, A. (2007b). A novel extracellular peroxidase and nucleases from a milky sap of Chelidonium majus. Fitoterapia, 78, 496-501. https://doi.org/10.1016/j.fitote.2007.04.012

Paik, J.Y., Jung, K.H., Lee, J.H., Park, J.W., \& Lee, K.H. (2017). Reactive oxygen species-driven HIF1 $\alpha$ triggers accelerated glycolysis in endothelial cells exposed to low oxygen tension. Nucl. Med. Biol., 45, 8-14. https://doi.org/10.1016/j.nucmedbio.2016.10.006

Păltinean, R., Mocan, A., Vlase, L., Gheldiu, A.M., Crișan, G., Ielciu, I., Voștinaru, O., \& Crișan, O. (2017). Evaluation of Polyphenolic Content, Antioxidant And Diuretic Activities Of Six Fumaria Species. Molecules, 22(4), 639. https://doi.org/10.3390/molecules22040639

Petruczynik, A., Tuzimski, T., Plech, T., Misiurek, J., Szalast, K., \& Szymczak, G. (2019). Comparison of Anticancer Activity and HPLC-DAD Determination Of Selected Isoquinoline Alkaloids From Thalictrum foetidum, Berberis sp. and Chelidonium majus Extracts. Molecules, 24(19), 3417. https://doi.org/10.3390/molecules24193417

Pisoschi, A.M., Pop, A., Cimpeanu, C., \& Predoi, G. (2016). Antioxidant Capacity Determination in Plants and PlantDerived Products: A Review. Oxid. Med.Cell Longev., 2016, 9130976. https://doi.org/10.1155/2016/9130976

Rahman, K. (2007). Studies on free radicals, antioxidants, and co-factors. Clin. Interv. Aging, 2(2), 219-36. PMID: 18044138; PMCID: PMC2684512.

Ratnam, D.V., Ankola, D.D., Bhardwaj, V., Sahana, D.K., \& Kumar, M.N. (2006). Role of antioxidants in prophylaxis and therapy: A pharmaceutical perspective. J. Control Release, 113(3), 189-207. https://doi.org/10.1016/j.jconrel.2006.04.015

Ravin, H.A. (1961). An improved colorimetric enzymatic assay of ceruloplasmin. J. Lab. Clin. Med., 58, 161-168.

Robin, H., \& Harley, J.D. (1967). Regulation of methaemoglobinaemia in horse and human 
erythrocytes. Aust. J. Exp. Biol. Med. Sci., 45(1), 77-88. https://doi.org/10.1038/icb.1967.4

Singh, I. (1996). Mammalian peroxisomes: metabolism of oxygen and reactive oxygen species. Ann. NY Acad. Sci., 804, 612-627.

https://doi.org/10.1111/j.1749-6632.1996.tb18648.X

Song, J.Y., Yang, H.O., Pyo, S.N., Jung, I.S., Yi, S.Y., \& Yun, Y.S. (2002). Immunomodulatory activity of protein-bound polysaccharide extracted from Chelidonium majus. Arch. Pharm. Res., 25(2), 158-164.

https://doi.org/10.1007/BF02976557

Srivastava, K.C., \& Shrivastava, D. (2016). Analysis of plasma lipid peroxidation and antioxidant enzymes status in patients of oral leukoplakia: A case control study. J. Int. Soc. Prev. Community Dent., 6(3), S213-S218. https://doi.org/10.4103/2231-0762.197195

Stanković, M.S., Nićiforović, N., Topuzović, M., \& Solujić, S. (2011). Total phenolic content, flavonoid concentrations and antioxidant activity of the whole plant and plant parts extracts from Teucrium montanum L. var. montnum, f. supinum (L.) Reichenb. Biotechnol. Biotechnol. Eq., 25, 2222-2227.

Stanković, M.S., Topuzović, M., Solujić, S., \& Mihailović, V. (2010). Antioxidant activity and concentration of phenols and flavonoids in the whole plant and plant parts of Teucrium chamaedrys L. var. glanduliferum Haussk. J. Med. Plant Res., 4, 2092-2098.

Stefanowski, N., Tkachenko, H., \& Kurhaluk, N. (2021a). Lipid peroxidation in the blood of rainbow trout(Oncorhynchus mykiss Walbaum) after incubation with extracts derived from stalks and roots of greater celandine (Chelidonium majus L.). Topical issues of new medicines development: Proceedings of the XXVIII International scientificpractical conference of young scientists and students dedicated to the $150^{\text {th }}$ anniversary of the birth of M.O. Valyashko (March 18-19, 2021, Kharkiv). Kharkiv: National Pharmaceutical University, 259-261.

Stefanowski, N., Tkachenko, H., \& Kurhaluk, N. (2021b). Biomarkers of oxidative stress in the blood of rainbow trout after in vitro treatment by extracts derived from Chelidonium majus L. Youth and Progress of Biology: Abstracts of XVII International Scientific Conference for Students and Ph.D. Students (Lviv, April 19-21, 2021). Lviv : LLC Romus-Poligraf, 69-70.
Storz, P. (2005). Reactive oxygen species in tumor progression. Front Biosci., 10, 1881-1896. https://doi.org/10.2741/1667

Su, L.J., Zhang, J.H., Gomez, H., Murugan, R., Hong, X., Xu, D., Jiang, F., \& Peng, Z.Y. (2019). Reactive Oxygen SpeciesInduced Lipid Peroxidation In Apoptosis, Autophagy, And Ferroptosis. Oxid. Med. Cell Longev., 2019, 5080843. https://doi.org/10.1155/2019/5080843

Unuofin, J.O., \& Lebelo, S.L. (2020). Antioxidant effects and mechanisms of medicinal plants and their bioactive compounds for the prevention and treatment of type 2 diabetes: An updated review. Oxid. Med.Cell Longev., 2020, 1356893. https://doi.org/10.1155/2020/1356893

Wright, R.O., Lewander, W.J., \& Woolf, A.D. (1999). Methemoglobinemia: etiology, pharmacology, and clinical management. Ann. Emerg. Med., 34(5), 646-656. https://doi.org/10.1016/s0196-0644(99)70167-8

Xiong, Q., Zhang, M., Wang, T., Wang, D., Sun, C., Bian, H., Li, P., Zou, Y., \& Xu, W. (2020). Lipid oxidation induced by heating in chicken meat and the relationship with oxidants and antioxidant enzymes activities. Poult. Sci., 99(3), 1761-1767. https://doi.org/10.1016/j.psj.2019.11.013

Zar, J.H. (1999). Biostatistical Analysis. $4^{\text {th }}$ ed., Prentice-Hall Inc., Englewood Cliffs, New Jersey.

Zielińska, S., Czerwińska, M.E., Dziągwa-Becker, M., Dryś, A., Kucharski, M., Jezierska-Domaradzka, A., Płachno, B.J., \& Matkowski, A. (2020). Modulatory effect of Chelidonium majus extract and its alkaloids on LPS-stimulated cytokine secretion in human neutrophils. Molecules, 25(4), 842. https://doi.org/10.3390/molecules25040842

Zielińska, S., Jezierska-Domaradzka, A., Wójciak-Kosior, M., Sowa, I., Junka, A., \& Matkowski, A.M. (2018). Greater celandine's Ups and Downs-21 centuries of medicinal uses of Chelidonium majus from the viewpoint of today's pharmacology. Front. Pharmacol., 9, 299. https://doi.org/10.3389/fphar.2018.00299 